\title{
Arteriovenous fistula mimicking vestibular schwannoma
}

\section{Figure 1 MRI, axial T1-weighted imaging} postcontrast

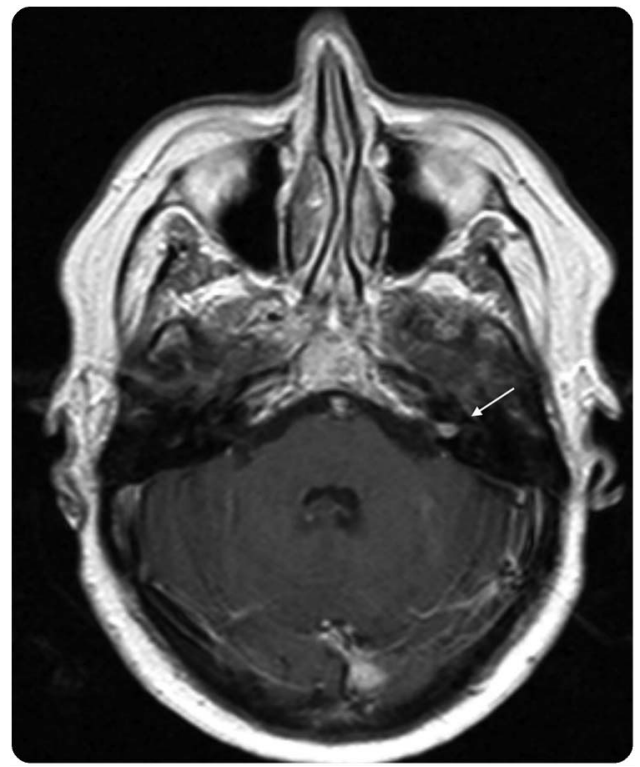

Axial T1-weighted image (postcontrast) shows an enhancing lesion of the left internal acoustic meatus consistent with vestibular schwannoma (arrow).

\section{Figure 2 Cerebral angiogram, anteroposterior view, midarterial phase, left vertebral artery injection}

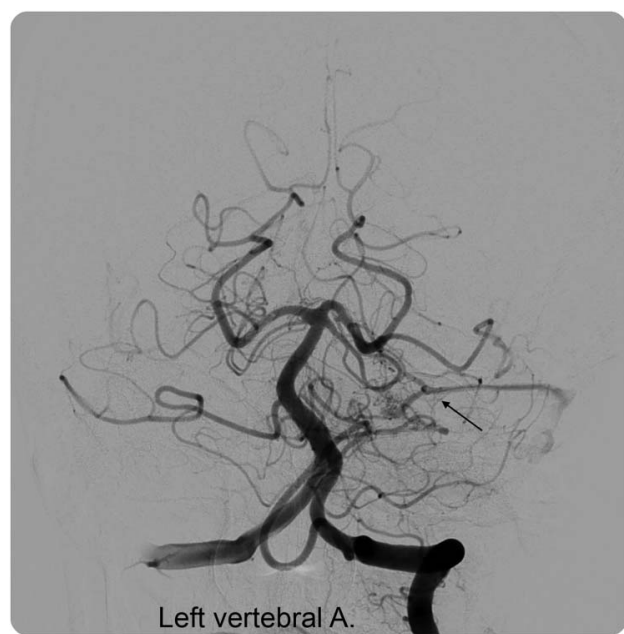

Cerebral angiogram anteroposterior view, midarterial phase, left vertebral artery injection shows early venous drainage into the superior petrosal sinus (arrow).

A 59-year-old woman presented with progressive left-sided sensorineural hearing loss. Workup revealed an enhancing lesion of the internal auditory canal (IAC) consistent with vestibular schwannoma (figure 1).

The patient underwent a translabyrinthine approach for resection of the mass. When the dura of the IAC was opened, no tumor was found but several large vessels were noted.

Cerebral angiography was performed and early venous drainage suggested an arteriovenous fistula, fed by the anterior inferior cerebellar artery, draining into the superior and inferior petrosal sinuses (figure 2).

\section{Neil Woodall, MD, Scott Y. Rahimi, MD}

From the Department of Neurological Surgery, Medical College of Georgia at Augusta University.

Author contributions: Dr. Woodall: literature review, manuscript preparation. Dr. Rahimi: project supervision.

Study funding: No targeted funding reported.

Disclosure: The authors report no disclosures relevant to the manuscript. Go to Neurology.org for full disclosures.

Correspondence to Dr. Woodall: mneilwoodall@gmail.com 


\title{
Neurology
}

\author{
Arteriovenous fistula mimicking vestibular schwannoma \\ M. Neil Woodall and Scott Y. Rahimi \\ Neurology 2016;87;1184 \\ DOI 10.1212/WNL.0000000000003103
}

This information is current as of September 12, 2016

\section{Updated Information \& Services \\ Subspecialty Collections}

Permissions \& Licensing

Reprints including high resolution figures, can be found at: http://n.neurology.org/content/87/11/1184.full

This article, along with others on similar topics, appears in the following collection(s):

\section{All Neurotology}

http://n.neurology.org/cgi/collection/all_neurotology

\section{Arteriovenous malformation}

http://n.neurology.org/cgi/collection/arteriovenous_malformation MRI

http://n.neurology.org/cgi/collection/mri

Information about reproducing this article in parts (figures,tables) or in its entirety can be found online at:

http://www.neurology.org/about/about_the_journal\#permissions

Information about ordering reprints can be found online:

http://n.neurology.org/subscribers/advertise

Neurology ${ }^{\circledR}$ is the official journal of the American Academy of Neurology. Published continuously since 1951, it is now a weekly with 48 issues per year. Copyright (O 2016 American Academy of Neurology. All rights reserved. Print ISSN: 0028-3878. Online ISSN: 1526-632X.

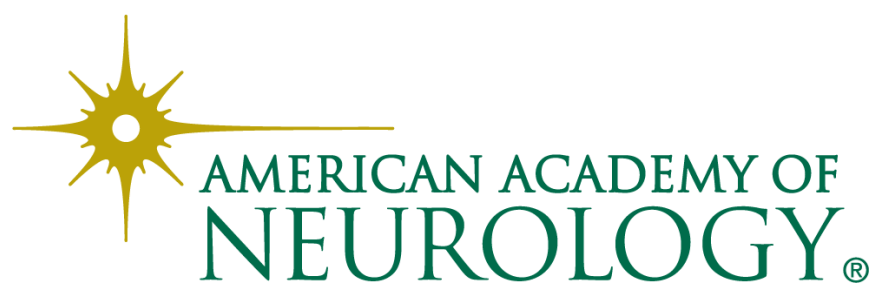

